Farrell, P. D., D. M. Baasch, J. M. Farnsworth, and C. B. Smith. 2018. Interior Least Tern and Piping Plover nest and brood survival at managed, off-channel sites along the central Platte River, Nebraska, USA 2001-2015. Avian Conservation and Ecology 13(1):1. https://doi.org/10.5751/ ACE-01133-130101

Copyright (C) 2018 by the author(s). Published here under license by the Resilience Alliance.

Research Paper

\title{
Interior Least Tern and Piping Plover nest and brood survival at managed, off-channel sites along the central Platte River, Nebraska, USA 2001-2015
}

\author{
Patrick D. Farrell ${ }^{1}$, David M. Baasch ${ }^{1}$, Jason M. Farnsworth ${ }^{1}$ and Chadwin B. Smith ${ }^{1}$ \\ ${ }^{1}$ Executive Director's Office for the Platte River Recovery Implementation Program
}

\begin{abstract}
The Platte River Recovery Implementation Program (PRRIP) and its partners invested substantial resources in creating and managing off-channel nesting habitat for Interior Least Terns (Sternula antillarum athalassos) and Piping Plovers (Charadrius melodus) along the central Platte River in Nebraska. Among other things, management activities implemented at nesting sites to increase nest and brood survival have included tree removal, construction of a water barrier surrounding the nesting areas, installation of predator fences, and predator trapping. We used 15 years of data at off-channel sites along the central Platte River to assess the influence of several biotic and abiotic variables on the survival of Interior Least Tern and Piping Plover nests and broods. We observed high survival rates for Interior Least Tern and Piping Plover nests and broods as two-thirds of Interior Least Tern and three-quarters of Piping Plover nests were successful and three-quarters of all Interior Least Tern and Piping Plover broods were successful. We found productivity of Interior Least Terns and Piping Plovers was reduced during both the nesting and brood-rearing stages by weatherrelated variables rather than variables the PRRIP can manage. As such, we conclude habitat management activities implemented at off-channel sites to date are sufficient for maintaining high levels of productivity for Interior Least Terns and Piping Plovers along the central Platte River.
\end{abstract}

\section{Survie des nids et des couvées de la Petite Sterne de l'intérieur et du Pluvier siffleur sur des sites hors chenal aménagés le long de la rivière Platte, Nebraska, États-Unis, 2001-2015}

RÉSUMÉ. Le programme de mise en !uvre du rétablissement « Platte River Recovery Implementation Program » (PRRIP) et ses partenaires ont investi des sommes considérables pour la création et l'aménagement d'habitat de nidification hors chenal pour les Petites Sternes de l'intérieur (Sternula antillarum athalassos) et les Pluviers siffleurs (Charadrius melodus) le long de la partie centrale de la rivière Platte au Nebraska. Entre autres choses, les activités d'aménagement mises en place sur les lieux de nidification pour augmenter la survie des nids et des couvées ont consisté au retrait d'arbres, à la construction d'une barrière d'eau entourant les secteurs de nidification, à l'installation de clôtures anti-prédateurs et à au piégeage de prédateurs. Au moyen de 15 années de données récoltées sur des sites hors chenal le long de la partie centrale de la rivière Platte, nous avons évalué l'effet de plusieurs variables biotiques et abiotiques sur la survie des nids et des couvées de Petites Sternes de l'intérieur et de Pluviers siffleurs. Nous avons observé des taux de survie de nids et de couvées élevés pour les deux espèces : deux tiers des nids de sternes et trois quarts des nids de pluviers ont eu du succès et trois quarts de toutes les couvées des deux espèces ont eu du succès. Nous avons découvert que la productivité des deux espèces était réduite, à l'étape de la nidification comme à celle de l'élevage des couvées, par des variables relatives aux conditions météorologiques plutôt que de variables sur lesquelles pouvait agir le PRRIP. Ainsi, nous concluons que les activités d'aménagement de l'habitat instaurées jusqu'à maintenant aux sites hors chenal sont suffisantes pour le maintien de hauts taux de productivité des Petites Sternes de l'intérieur et des Pluviers siffleurs le long de la rivière Platte.

Key Words: Central Platte River; Charadrius melodus; Interior Least Tern; off-channel habitat; Piping Plover; sandpit; Sternula antillarum athalassos; survival

\section{INTRODUCTION}

The Platte River Recovery Implementation Program (PRRIP) is tasked with improving Interior Least Tern (Sternula antillarum athalassos; hereafter, Least Tern) and Piping Plover (Charadrius melodus) use and productivity along $145 \mathrm{~km}$ of the Platte River in central Nebraska, USA. Program activities in this reach, known as the Associated Habitat Reach (AHR), are intended to mitigate declines in species habitat suitability due to water development in the Platte River basin (Department of the Interior 2006). As such, the PRRIP has invested substantial resources in creating and maintaining nesting habitat for these threatened or endangered species within the AHR.

There are a number of examples in which management of reservoirs and riverine systems presents threats to the nesting success of avian species (Brown and Johnson 1985, Whitehead and Tschirner 1990, Bayard and Elphick 2011, Anteau et al. 2012, 
Sherfy et al. 2012). Inundation from flooding and loss of eggs and chicks can greatly reduce Least Tern and Piping Plover productivity (Faanes 1983, Sidle et al. 1992, Dugger et al. 2000, 2002, Szell and Woodrey 2003). The number of fledglings produced per adult pair was negatively correlated with mean and maximum river elevations during July on the Mississippi River (Dugger et al. 2002). Water levels on the Platte River generally increase in late spring between the time Piping Plovers initiate and hatch nests, which is a result of Rocky Mountain snow melt and local precipitation. These increases result in the need for elevated habitat for Least Terns and elevated habitat near the shoreline for Piping Plovers to provide foraging opportunities within their territory and yet avoid inundation due to rising river levels (Anteau et al. 2012, Baasch et. al 2017). Elevated nesting habitat primarily exists only on managed off-channel sandpits and constructed off-channel sand and water sites within the AHR. As such, Least Terns and Piping Plovers primarily nest on offchannel habitat along the central Platte River where inundation is not a great concern due to the elevation at which these sites are constructed.

Regardless of habitat type, several other factors influence reproductive success of Least Terns and Piping Plovers including predation, density dependence, and weather (Burger 1987, Patterson et al. 1991, Melvin et al. 1992, Loegering and Fraser 1995, Goldin and Regosin 1998, Elias et al. 2000). Nests established closer to wooded areas provide predator perches for avian species, and such nests may experience greater predation (Maxson and Haws 2000, Kruse et al. 2001, Murphy et al. 2003). Decreased productivity from predation has occurred, and local instances have been devastating for breeding birds (Kirsch 1996, Kruse et al. 2001, Szell and Woodrey 2003, Le Fer et al. 2008, Catlin et al. 2011, Brooks et al. 2013). Because predation can be an important source of nest failure, the PRRIP has managed impacts of predation by removing wooded areas within $60 \mathrm{~m}$ of the nesting area, installing predator fences at all managed offchannel sites, and implementing trapping to reduce predator densities surrounding the nesting areas.

The density of breeding pairs can also influence nest and brood loss to predation and can lead to interspecific and intraspecific interactions that impact avian productivity (Burger 1987, 1988, Brunton 1997, 1999, Anteau et al. 2014). Interspecific and intraspecific associations are important factors driving establishment of nests and likely influence nest site selection patterns by both species (Burger 1988, Sherfy et al. 2012, Baasch et al. 2017). Social factors and spacing within mixed colonies of California Least Terns (Sterna antillarum browni) and Snowy Plovers (Charadrius nivosus) and Semipalmated Plovers (Charadrius semipalmatus) in response to Arctic Terns (Sterna paradisaea) have been linked to productivity, but costs or benefits of mixed-species nesting for Least Terns and Piping Plovers have received relatively little attention (Burger 1987, Powell 2001, Nguyen et al. 2006, Sherfy et al. 2012). Due to nesting chronology, similarities in habitat selection by each of the species could lead to the best nest sites being occupied by Piping Plovers and could force Least Terns to nest in suboptimal habitat where survival is reduced, or interspecific associations may prove beneficial for both species. Evaluating survival based on space use and associations by both species simultaneously will aid in refining habitat management objectives for the benefit of both Least Terns and Piping Plovers (Sherfy et al. 2012).
Avian productivity can also be greatly influenced by temperature and weather events such as storms. Extreme daily minimum and maximum temperatures can negatively impact productivity, especially maximum temperatures (Jenks-Jay 1982, Krogh and Schweitzer 1999, Schweitzer and Leslie 1999, Harris et al. 2005). Nest and brood success are highest when nests are established close to the peak of the breeding season when timing of nesting and hatching coincides with less extreme temperatures and fewer extreme weather events as opposed to very early or late in the season (Murphy et al. 2000, Cohen et al. 2009, McGowan et al. 2009). Extreme weather events (e.g., hail, intense rain, etc.) and increased frequency of exposure to such events decreases daily survival rates for nests and broods by increasing parental investment in incubation and through direct loss of eggs or chicks (Dinan 1982, Harris et al. 2005, Brooks et al. 2013).

The importance of habitat quality, nest and chick predation, interspecific and intraspecific associations, and weather on population dynamics and reproductive success of Least Terns and Piping Plovers is poorly understood (Cohen et al. 2009). To date, the PRRIP and its partners have implemented targeted management actions, such as removing trees around nesting areas, in an effort to reduce the impact of predation on productivity; however, the influence of these activities has never been evaluated for off-channel nesting sites. The objectives of our study included quantifying Least Tern and Piping Plover nest and brood survival during a 15 -yr period and identifying important management actions and environmental and ecological conditions that influence Least Tern and Piping Plover productivity on managed off-channel sites within the AHR. Identifying these factors is an important step in prioritizing and designing management strategies for increasing and maintaining high reproductive success. Information that increases our understanding of the Least Tern and Piping Plover survival and productivity on offchannel nesting habitats will enhance our ability to conserve and manage these threatened or endangered populations. Results of this study will be used to help understand variables that limit productivity on managed off-channel sites and provide empirically driven modifications to current off-channel management practices to improve Least Tern and Piping Plover productivity.

\section{METHODS}

\section{Study area}

The AHR for the PRRIP is a $145-\mathrm{km}$ reach extending from Lexington, Nebraska, downstream to Chapman, Nebraska, USA, and encompasses central Platte River channels and offchannel habitats (sandpits and constructed off-channel sand and water sites) within $5.6 \mathrm{~km}$ of the river (Fig. 1). Only three managed, off-channel nesting sites were present in 2001, but creation of new and restoration of existing sites increased the number of nesting sites to nine by 2013 and all were maintained through 2015. Management activities at each site included predator fencing and trapping, pre-emergent herbicide application, and tree removal. All sites were moated on at least three sides by $\geq 15 \mathrm{~m}$ of water, and the remaining peninsula was fenced to reduce predator access. Predator fencing and trapping have not occurred at Trust Wildrose East; however, the nesting area was completely moated by water. We used the PRRIP's 
Fig. 1. Associated Habitat Reach (AHR) of the central Platte River extending from Lexington downstream to Chapman, Nebraska. Nine managed, off-channel nesting sites were included in the productivity analysis and were included as point features.

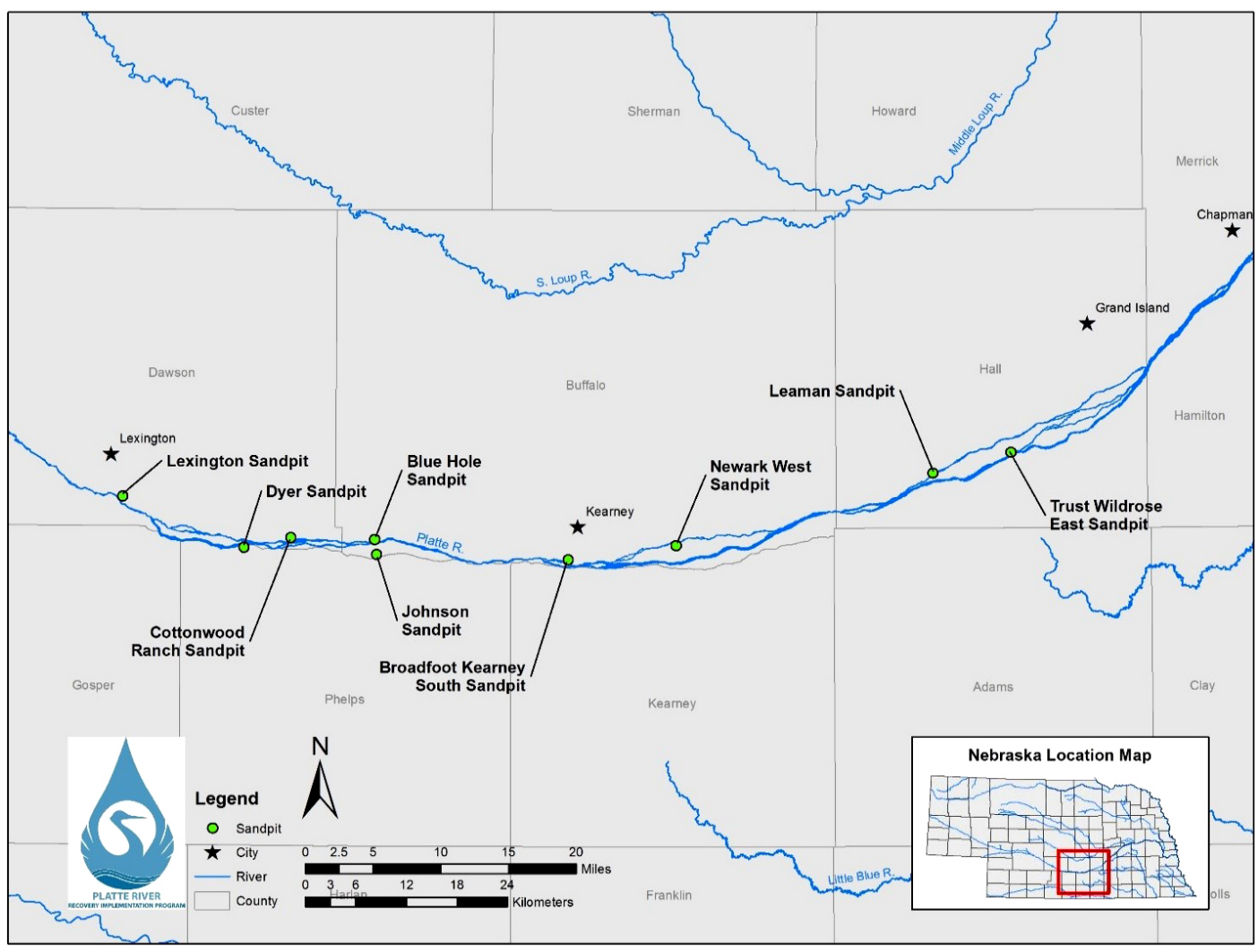

minimum habitat criteria to identify suitable habitat at each site and determine the amount of nesting habitat available each year, and a breeding-pair estimator to estimate numbers and densities of breeding pairs (PRRIP 2012, Baasch et al. 2015, Keldsen and Baasch 2017).

\section{Data}

During the nesting seasons of 2001-2015, all managed offchannel nesting sites were surveyed semimonthly to document Least Tern and Piping Plover productivity. Sites where any nest or brood was documented were monitored at least twice weekly (occasionally up to five times weekly) from 15 April to 15 September. Piping Plovers generally start to initiate nests earlier in the year than Least Terns in our study area, and the monitoring season duration was set to capture the breeding activity of both species (Keldsen and Baasch 2017). Monitoring objectives were to locate and document Least Tern and Piping Plover adults, nests, chicks, fledglings, and breeding pairs to document species productivity. Surveys included observations from $>50$ m outside of the nesting habitat area using spotting scopes and binoculars (2001-2015) as well as entering active sites to walk through nesting areas to identify nest locations based on systematic, $10-\mathrm{m}$ grid searches that were conducted at least twice weekly (2009-2015; PRRIP 2015a). When an active nest was located, the date was recorded, and a GPS point was taken for the nest location. Active nests were defined as any scrape containing at least one egg. Active nests were monitored at least twice weekly until successful (at least one chick observed hatched), failed (evidence of nest destruction or abandonment), or unknown fates (no evidence present) were determined. If a brood was observed, but the associated nest was not, the brood was still included in the brood survival analysis. Broods were considered fledged when chicks were observed in sustained flight or were observed at 21 (Least Tern) or 28 (Piping Plovers) days of age. Due to our intense survey efforts, nests were most generally observed within the first one or two days of incubation, and we were able to assume the probability of detection was one.

\section{Statistical analyses}

To use productivity information for nest and brood survival analyses, several pieces of information were used including: (1) the day the nest or brood was found; (2) the last day the nest or brood was active; (3) the day the nest or brood was fated as successful or failed; (4) nest or brood fate (successful or fledged $=0$, respectively, or failed $=1$ ); and (5) the frequency of nests and broods with each history (frequency $=1$ ). Dates were standardized to include only the breeding season for Least Terns and Piping Plovers, which we designated as 15 April-15 September.

We calculated nest and brood daily survival rate (DSR) and the incubation and brooding period survival rates $\left(D_{S R}{ }^{\mathrm{n}}\right)$ separately for each species where $n$ was $21 \mathrm{~d}$ for Least Tern nests and broods and $28 \mathrm{~d}$ for Piping Plover nests and broods using logistic regression models with a logit link function (Rotellam et al. 2000). 
Table 1. Summary statistics for Interior Least Tern (LETE) and Piping Plover (PIPL) nest and brood explanatory variables.

\begin{tabular}{|c|c|c|c|c|c|c|c|c|c|}
\hline & Metric & $\begin{array}{l}\text { Date First } \\
\text { Found }\end{array}$ & $\begin{array}{c}\text { Max Temp } \\
\left({ }^{\circ} \mathrm{C}\right)\end{array}$ & $\begin{array}{c}\text { Min Temp } \\
\left({ }^{\circ} \mathrm{C}\right)\end{array}$ & $\begin{array}{c}\text { LETE Breeding } \\
\text { Pair Density } \\
\text { (Pairs/hectare) }\end{array}$ & $\begin{array}{c}\text { PIPL Breeding } \\
\text { Pair Density } \\
\text { (Pairs/hectare) }\end{array}$ & $\begin{array}{l}\text { Elevation } \\
(\mathrm{m})\end{array}$ & $\begin{array}{c}\text { Distance to } \\
\text { Predator } \\
\text { Perch }(\mathrm{m})\end{array}$ & $\begin{array}{c}\text { Number of } \\
\text { Storm } \\
\text { Events }\end{array}$ \\
\hline \multirow[t]{2}{*}{ LETE Nest } & Average & 17 June & 35 & 10 & 0.45 & 0.12 & 2.15 & 168.90 & 0.13 \\
\hline & $\mathrm{SD}$ & $15 \mathrm{~d}$ & 3 & 3 & 0.44 & 0.09 & 1.00 & 71.63 & 0.46 \\
\hline \multirow[t]{2}{*}{ LETE Brood } & Average & 17 July & 36 & 12 & 1.30 & 0.26 & NA & NA & 0.02 \\
\hline & $\mathrm{SD}$ & $13 \mathrm{~d}$ & 2 & 3 & 1.29 & 0.24 & NA & NA & 0.14 \\
\hline \multirow[t]{2}{*}{ PIPL Nest } & Average & 17 May & 34 & 4 & 0.23 & 0.13 & 2.09 & 167.45 & 0.10 \\
\hline & $\mathrm{SD}$ & $18 \mathrm{~d}$ & 4 & 4 & 0.37 & 0.08 & 0.90 & 63.82 & 0.38 \\
\hline \multirow[t]{2}{*}{ PIPL Brood } & Average & 17 June & 36 & 10 & 0.35 & 0.12 & NA & NA & 0.19 \\
\hline & $\mathrm{SD}$ & $18 \mathrm{~d}$ & 3 & 3 & 0.39 & 0.08 & NA & NA & 0.62 \\
\hline
\end{tabular}

Variables were included as a priori hypotheses that included: daily survival rate was constant across nest sites (NS) and year and that date first found; deviation from average, maximum, and minimum temperature (MaxTD and MinTD, respectively); storm events (S) and Piping Plover breeding pair density (PPBPD) all negatively impact daily survival rate (Table 1). Distance to predator perch (DPP), elevation above water (EAW), and Least Tern breeding pair density (LTBPD) were hypothesized to positively impact daily survival rate (Table 1).

Given the intensity of survey efforts, the day a nest or brood was first found was assumed to closely approximate the initiation date. Thus, the date a nest or brood was first observed was used to investigate how nest initiation and hatch date influenced nest and brood survival. We calculated the mean and standard deviations based on the distribution of initiation dates for nests and hatching dates for broods. We used this information to calculate the number of standard deviations from the mean each nest and brood were. Similarly, daily minimum and maximum temperatures were recorded for each day a nest or brood was active. Using this information, the maximum and minimum temperatures were calculated for each nest and brood, and then the overall average and standard deviations of temperatures were calculated across all nests or broods separately for each species. The number of absolute standard deviations from the average maximum and minimum temperatures was then recorded for each nest or brood. We used notes recorded within our monitoring data regarding nest and brood failures due to weather to get the most accurate information on when sites were exposed to severe storm events. We also used weather data from the National Oceanic and Atmospheric Administration (NOAA) station nearest each site to confirm weather events when nests and broods were recorded to have failed due to weather. Storm events were nest or brood specific and were identified as any weather event attributed to the failure of at least one nest or brood at a site.

We also calculated habitat values for attributes hypothesized to influence nest and brood survival. To reduce error and maintain consistency, aerial photographs ( $\leq 1-\mathrm{m}$ resolution) collected during the nesting season by the USDA Farm Service Agency National Agriculture Imagery Program (NAIP; 2001-2006; USDA Natural Resources Conservation Service et al. 2016) or study-area specific, $15.24-\mathrm{cm}$ (6-inch) color infrared aerial photography (2007-2015) and GPS locations of nests were used to determine distance to nearest to woody vegetation $>3 \mathrm{~m}$ in height (predator perch) and nearest Least Tern and Piping Plover nest present when each nest was initiated. All distance measures were collected in ArcGIS (Environmental Systems Research Institute (ESRI) 2011). We used LiDAR data collected by the PRRIP to calculate the elevation of each nest above the waterline. We used PRRIP-defined suitable nesting area at each site to determine the breeding pair density for each species (PRRIP 2012). Densities of breeding pairs were calculated daily, and the average breeding pair densities of Least Terns and Piping Plovers were calculated for each individual nest or brood during their active periods.

We used the nest survival model in package RMARK in Program $\mathrm{R}$ for nest and brood survival analyses (Dinsmore et al. 2002, Laake et al. 2013, R Development Core Team 2015). We included variables in 12 a priori models to quantify the influence each variable had on survival rates of nests and nine a priori models to quantify the influence each variable had on survival rates of broods for each species, both of which included null as a model for comparison (Table 2). Models were compared using Akaike Information Criterion adjusted for small sample size (AICc; Burnham and Anderson 2002). We reported daily survival rates and the influence variables in the top models have on survival rates for Least Tern and Piping Plover nests and broods. When multiple models had $\triangle \mathrm{AICc} \leq 2.0$, we considered the most parsimonious model the top model to safeguard against overly complex selections. When temperature variables were included in the top model, relationships were back transformed to degrees Celsius and projected from lowest to highest maximum temperature recorded for each relevant nest or brood group.

\section{RESULTS}

We observed 937 of 1,165 Least Tern nests and 316 of 420 Piping Plover nests with enough information to determine nest fate with certainty on the nine managed off-channel sites within the AHR, 2001-2015. The numbers of Least Tern and Piping Plover nests and broods were fairly stable from 2001-2009 and then increased through 2015 (Fig. 2). The greatest numbers of Least Tern nests and broods were observed in 2015 (149 nests and 101 broods), whereas the lowest number of nests was observed in 2001 (24 nests) and the lowest number of broods in 2001, 2006, and 2008 (19 broods). The greatest number of Piping Plover nests was also observed in 2015 (46 nests), whereas the greatest number of broods was observed in 2014 and 2015 (32 broods). We observed the fewest Piping Plover nests in 2001 (seven nests), and fewest broods were observed in 2009 (eight broods). Six hundred and eleven Least Tern nests were documented as successful, and overall daily nest survival rate was estimated at 0.9795 (95\% CI: 0.9770-0.9817), whereas incubation period survival was 
Table 2. A priori models used to estimate incubation and brooding period survival for Interior Least Tern and Piping Plover nests and broods within the AHR, 2001-2015. Variables included nest site (NS), Interior Least Tern and Piping Plover breeding pair density (LTBPD and PPBPD, respectively), initiation date (Date), year, standard deviations from average maximum temperature (MaxTD), standard deviations from average minimum temperature (MinTD), storm events (S), elevation above water (EAW), and distance to predator perch (DPP).

\begin{tabular}{|c|c|c|c|c|}
\hline \multirow[b]{2}{*}{ Model } & \multicolumn{2}{|c|}{ Nest Survival } & \multicolumn{2}{|c|}{ Brood Survival } \\
\hline & Model Type & Variables $^{\dagger}$ & Model Type & Variables $^{\dagger}$ \\
\hline 1 & Constant & Null & Constant & Null \\
\hline 2 & Spatial & NS & Spatial & NS \\
\hline 3 & Temporal & Date & Temporal & Date \\
\hline 4 & Temporal & Year & Temporal & Year \\
\hline 5 & Weather & MaxTD & Weather & $\operatorname{Max} T D+M i n T D+S$ \\
\hline 6 & Weather & MinTD & Weather & MaxTD \\
\hline 7 & Weather & $\mathrm{S}$ & Weather & MinTD \\
\hline 8 & Weather & $\operatorname{Max} T D+M i n T D+S$ & Weather & $\mathrm{S}$ \\
\hline 9 & Ecological & LTBPD & Ecological & LTBPD \\
\hline 10 & Ecological & PPBPD & Ecological & PPBPD \\
\hline 11 & Habitat & EAW & & \\
\hline 12 & Habitat & DPP & & \\
\hline
\end{tabular}

Breeding Pair Density (BPD) was species and site specific

estimated at 0.6468 (95\% CI: $0.6135-0.6780)$. Of the 588 broods initially observed with enough information to determine fate, 450 broods were determined to have fledged at least one chick, and overall daily brood survival rate was estimated at 0.9872 (95\% CI: $0.9846-0.9893)$, and overall brood period survival was estimated at 0.7624 (95\% CI: $0.7224-0.7975)$. Two hundred and forty-two Piping Plover nests were documented as successful, and overall daily nest survival rate was estimated at 0.9901 (95\% CI: $0.9873-$ $0.9922)$, whereas incubation period survival was estimated at 0.7565 (95\% CI: 0.6996-0.8042). One-hundred and ninety-one Piping Plover broods fledged at least one chick of the 254 broods initially observed with enough information to determine fate, and overall daily brood survival rate was estimated at 0.9894 ( $95 \% \mathrm{CI}$ : $0.9857-0.9922)$, and overall brood period survival was estimated at $0.7424(95 \% \mathrm{CI}: 0.6674-0.8031)$. Several nests were not observed before hatching, which accounts for more broods being analyzed than successful nests counted.

Weather variables, including minimum temperature deviation, maximum temperature deviation, and storm events, were included

Fig. 2. Yearly counts of Interior Least Tern and Piping Plover nests and broods at off-channel nest sites in the Associated Habitat Reach from 2001-2015.

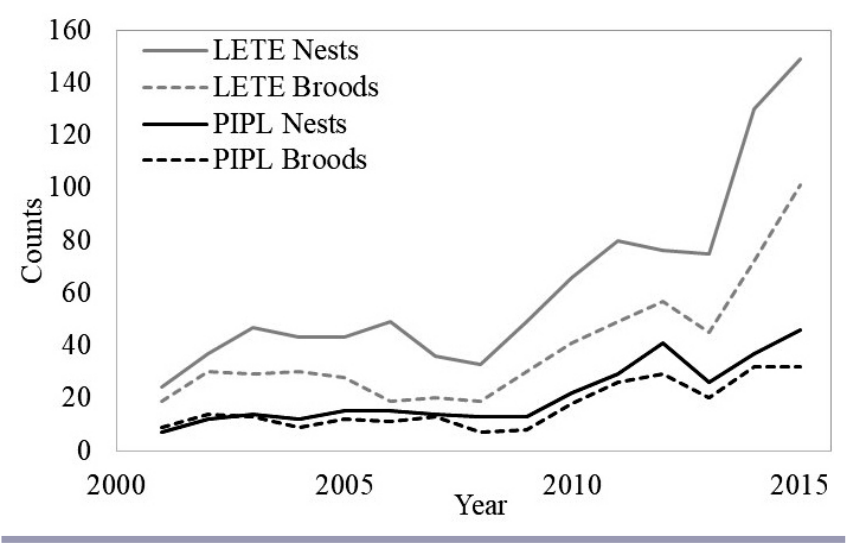

in the top models that best explained patterns of daily nest and brood survival for Least Tern and Piping Plover (Table 3). Maximum temperature was included in the top model for nest and brood analyses for both species where daily survival rates decreased as maximum temperatures deviated from the average observed by nests or broods during the study duration (Figs. 3, 4). Minimum temperature and storm events were also included in the top model for Least Tern nest and Piping Plover brood analyses where daily survival rates decreased as minimum temperatures deviated from the average temperatures observed for nests or broods during the study duration, and storm events had a variable relationship with low certainty of relationship (Figs. 3, 4).

Fig. 3. Influence of variables included in the best model, with $95 \%$ confidence intervals, on predicted daily survival rate (DSR; left) for Interior Least Tern nests (A-C) and broods (D).
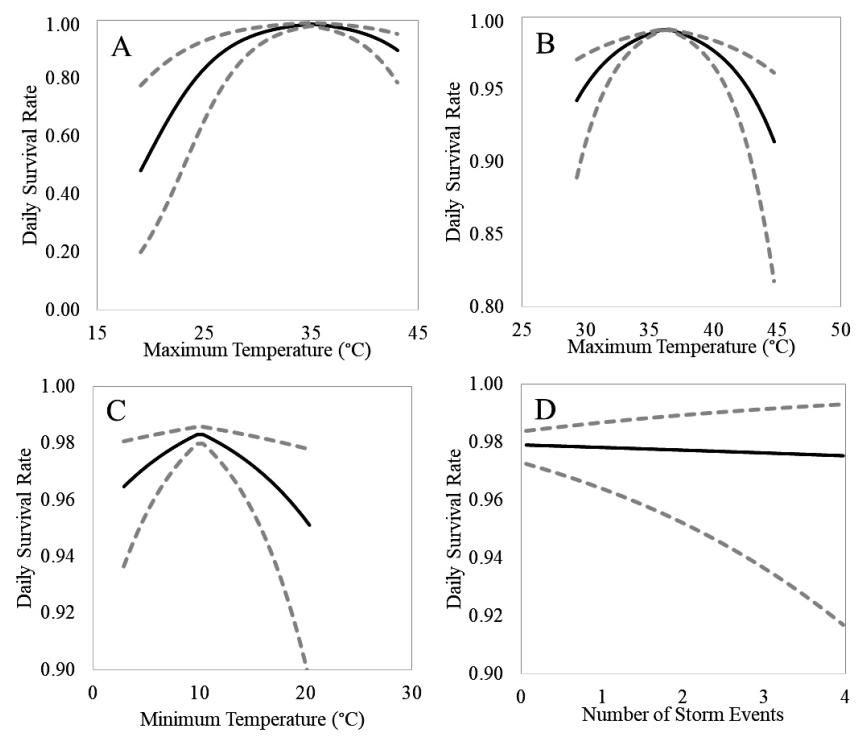
Table 3. Top five models, as ranked by AICc statistic, that best predict Interior Least Tern and Piping Plover nest and brood daily survival rates at nine managed off-channel sites in the Associated Habitat Reach, 2001-2015. Variables included nest site (NS), Interior Least Tern and Piping Plover breeding pair density (LTBPD and PPBPD, respectively), initiation date (Date), year, standard deviations from average maximum temperature (MaxTD), standard deviations from average minimum temperature (MinTD), storm events (S), elevation above water (EAW), and distance to predator perch (DPP).

\begin{tabular}{|c|c|c|c|c|c|c|}
\hline & Model & Parameters & $\mathrm{AICc}$ & $\triangle \mathrm{AICc}$ & Weight & Deviance \\
\hline \multirow[t]{5}{*}{ Least Tern Nest } & $\operatorname{MaxTD}+\operatorname{MinTD}+\mathrm{S}$ & 4 & 2722.50 & 0.00 & 0.97 & 2714.50 \\
\hline & MaxTD & 2 & 2729.45 & 6.94 & 0.03 & 2725.45 \\
\hline & MinTD & 2 & 2799.53 & 77.03 & 0.00 & 2795.53 \\
\hline & Date & 2 & 2800.91 & 78.41 & 0.00 & 2796.91 \\
\hline & PPBPD & 2 & 2805.12 & 82.62 & 0.00 & 2801.12 \\
\hline \multirow[t]{5}{*}{ Least Tern Brood } & MaxTD & 2 & 1202.90 & 0.00 & 0.73 & 1198.90 \\
\hline & $\operatorname{MaxTD}+\operatorname{MinTD}+\mathrm{S}$ & 4 & 1204.85 & 1.94 & 0.27 & 1196.84 \\
\hline & Date & 2 & 1218.24 & 15.34 & 0.00 & 1214.24 \\
\hline & Year & 2 & 1221.91 & 19.01 & 0.00 & 1217.91 \\
\hline & MinTD & 2 & 1225.72 & 22.82 & 0.00 & 1221.72 \\
\hline \multirow[t]{5}{*}{ Piping Plover Nest } & MaxTD & 2 & 707.26 & 0.00 & 0.87 & 703.26 \\
\hline & $\operatorname{MaxTD}+\operatorname{MinTD}+\mathrm{S}$ & 4 & 711.09 & 3.83 & 0.13 & 703.09 \\
\hline & LTBPD & 2 & 726.74 & 19.47 & 0.00 & 722.73 \\
\hline & EAW & 2 & 735.21 & 27.95 & 0.00 & 731.21 \\
\hline & $\mathrm{DPP}+\mathrm{EAW}$ & 3 & 735.39 & 28.13 & 0.00 & 729.39 \\
\hline \multirow[t]{5}{*}{ Piping Plover Brood } & $\operatorname{MaxTD}+\operatorname{MinTD}+\mathrm{S}$ & 4 & 577.45 & 0.00 & 0.61 & 569.44 \\
\hline & NS & 9 & 578.34 & 0.89 & 0.39 & 560.30 \\
\hline & MaxTD & 2 & 587.02 & 9.58 & 0.01 & 583.02 \\
\hline & MinTD & 2 & 591.74 & 14.29 & 0.00 & 587.73 \\
\hline & $\mathrm{S}$ & 2 & 593.67 & 16.22 & 0.00 & 589.67 \\
\hline
\end{tabular}

Fig. 4. Influence of variables included in the best model, with $95 \%$ confidence intervals or standard errors, on predicted daily survival rate (DSR; left) for Piping Plover nests (A) and broods (B-D).
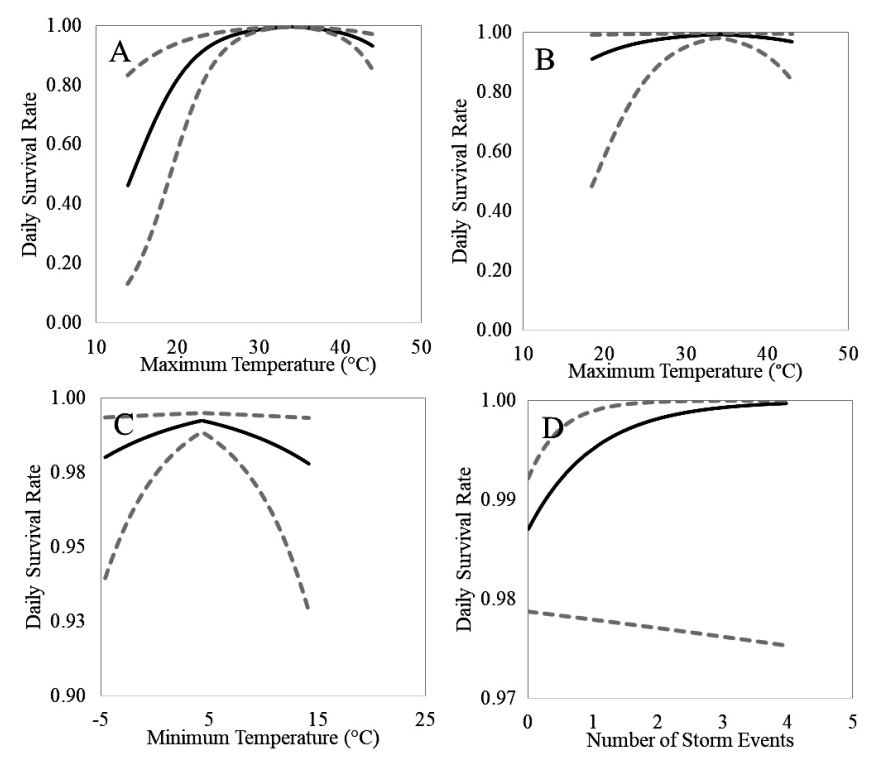

\section{DISCUSSION}

Piping Plovers and Least Terns historically used breeding habitats on off-channel sandpits and sandbars of the Platte River, but recently sandpits appear to have become the preferred breeding habitat for these populations, especially along the central Platte River. As such, several off-channel sites have been created and managed specifically to provide nesting areas alongside channels of the central Platte River for Least Terns and Piping Plovers (PRRIP 2006). Sandpit sites have been used extensively by Least Terns and Piping Plovers, even during years of drought (20012006) when natural sandbar habitat should have been readily available in the adjacent central Platte River. Fifteen years of implementing a standardized monitoring protocol in the AHR provided sufficient information to explore factors hypothesized to influence productivity of Least Terns and Piping Plovers at offchannel sites along the central Platte River. This compilation of data at nine managed off-channel sites within the AHR allowed for an extensive investigation into nest and brood survival to identify trends over a longer temporal period than had ever been investigated for the central Platte River. We limited our scope to Least Tern and Piping Plover productivity on managed offchannel sites within Nebraska along the central Platte River. Breeding activities by Least Tern and Piping Plover have occurred at off-channel sites without management activities and on inchannel sites, but were excluded from this investigation due to variability of site conditions and the limited amount of nesting activity. These sites accounted for $<5 \%$ of all nests and broods within the area of study during its duration. Similar to our study, $88 \%$ of Least Tern nests and $75 \%$ of Piping Plover nests along the central Platte River were located on managed sandpit habitats between 1979 and 2003 (Jenniges and Plettner 2008, PRRIP 2015b).

Similar to Jenniges and Plettner (2008), we observed high success rates for Least Tern nests and broods as $65 \%$ of all nests hatched at least one chick and $76 \%$ of all broods resulted in at least one fledgling on managed off-channel sites. The observed and model- 
predicted nest success estimates for sandpit sites are higher than those observed on in-channel sandbars along the central Platte River and at many other sites throughout both species' ranges (Anteau et al. 2012, Keldsen and Baasch 2017). Apparent nest survival rates on the Missouri River were also much higher on artificial as opposed to natural sandbar habitats (Sherfy et al. 2012). On the Lower Mississippi River, nest success for Least Terns between 1995 and 1997 averaged 61\% (range 0.40-0.97; Szell and Woodrey 2003). Similarly, Sherfy et al. (2012) found only $39 \%$ of all known-fate nests hatched on natural sandbars whereas $70 \%$ of all known-fate nests hatched on constructed sandbars on the Missouri River. We also observed high success rates for Piping Plover nests and broods as $77 \%$ of all nests hatched at least one chick and $75 \%$ of all broods resulted in at least one fledgling.

The brooding period survival rate on the Missouri River between 1993 and 2005 ranged from 0.126 to 0.188 , which is much lower than our estimated survival rates ( $>0.74)$; however, McGowan et al. (2009) used a modified catch-curve analysis and only surveyed five periods during the middle of the nesting season, whereas we used logistic regression models and sampled more intensively throughout the nesting and brood-rearing season. Daily nest survival rates on alkali wetlands and epilimnetic riverine sandbars on the Missouri River were lower (0.92-0.93) than what we observed $(>0.98)$, whereas daily survival rates on hypolimnetic sandbars on the Missouri River were similar (0.99) to what was observed on off-channel sites along the central Platte River. Our daily survival rates were also slightly higher than what was observed on Assateague Island National Seashore, Maryland, USA (0.96) and on New York barrier islands, USA (0.96-0.98; Loegering and Fraser 1995, Elias et al. 2000). Daily survival rates for Piping Plovers at two sites in New York, USA over an 11-yr period (1994-2004) averaged 0.766 and 0.879 , and chick survival averaged 0.834 and 0.230 (Cohen et al. 2009).

Extreme temperature conditions and weather events can have a great influence on nesting or brooding Least Terns and Piping Plovers (Dinan 1982, Krogh and Schweitzer 1999, Schweitzer and Leslie 2000, Harris et al. 2005, Whittier and Leslie 2009). We found high and low temperatures in the AHR influenced Least Tern nest and brood survival and Piping Plover nest survival more than any other metric we tested. Eggs can be especially impacted by extreme temperatures due to lack of mobility and embryonic development that is sensitive to temperature conditions (Whitman 1988, Thompson et al. 1997). Similarly, chicks have a limited ability to thermoregulate before fledging, thus we found Least Tern and Piping Plover brood survival was also susceptible to changes in temperature (Howell 1959, Krogh and Schweitzer 1999). Storm events were found to have positive and negative influences on survival, but positive relationships in particular were highly uncertain. Ideally, we would have had a weather station at each site to more directly document all storm events and better evaluate the influence storm events have on nest and brood survival, but those data were not available. We believe weatherrelated losses to nests and chicks are likely to be an increasing threat if the climate changes, as there may be an increase in the frequency of extreme weather events.

Similar to Cohen et al. (2009), we were unable to establish a relationship between nest success rates and nesting-pair density, and the habitat variables we evaluated were not found to influence nesting and brood-rearing period survival. Rather, productivity of Least Terns and Piping Plovers was reduced during both the nesting and brood-rearing stages by weather-related factors that are impossible to mitigate or manage for. This finding indicates current habitat management activities at off-channel sites create conditions that are, at the very least, not negatively impacting nesting and brood-rearing period survival of Least Terns and Piping Plovers. To date, the PRRIP and its partners have implemented management strategies such as providing dry sand areas for nesting during times of high water, removing woody vegetation $\leq 60 \mathrm{~m}$ from the nesting areas, constructing a water barrier $\geq 15 \mathrm{~m}$ around nesting areas, and reducing predation through predator trapping and fencing at all sites. If a more experimental system were present, varying management techniques could have been implemented to explore a wider range of values in each of the habitat covariates and would have allowed us to investigate these metrics more directly.

Availability and quality of breeding habitats are critical to the conservation of Least Terns and Piping Plovers (Elliott-Smith and Haig 2004, Anteau et al. 2012). An extraordinary challenge for these species is that there can be shifts in availability and quality of habitats within reservoir, river sandbar, and wetland nesting habitats in response to local weather events and water management activities within natural habitats in which both species have evolved. Thus, managers seem to be interested in creating or enhancing habitat in alternative ways (Sherfy et al. 2009, Anteau et al. 2012). Sandpits appear to provide a source population for Least Terns and Piping Plovers given the populations of both species continued to increase as additional nesting habitat was created within the AHR. As such, off-channel nesting sites may prove to be a viable option for maintaining these species as the human population demands for water increase and water management practices continue to threaten their existence on wetland, in-channel sandbar, and shoreline-reservoir habitat. Management practices such as removing trees and predators in close proximity to nesting areas have decreased threats to Least Tern and Piping Plover productivity and increased the overall suitability of nesting habitat in accordance with the PRRIP's species' management plans (PRRIP 2006). As such, we recommend the continuation of current management practices at off-channel sites along the central Platte River.

Responses to this article can be read online at: http://www.ace-eco.org/issues/responses.php/1133

\section{Acknowledgments:}

We would like to thank all members of the Platte River Recovery Implementation PRRIP's Technical Advisory Committee, three anonymous reviewers, and the Associate Editor for their helpful and insightful comments. The Platte River Recovery Implementation Program provided funding for this research. All applicable ethical guidelines for the use of birds in research have been followed, including those presented in the Ornithological Council's "Guidelines to the use of wild birds in research" (Fair et al. 2010). 


\section{LITERATURE CITED}

Anteau, M. J., T. L. Shaffer, M. H. Sherfy, M. A. Sovada, J. H. Stucker, and M. T. Wiltermuth. 2012. Nest survival of Piping Plovers at a dynamic reservoir indicates an ecological trap for a threatened population. Oecologia 170(4):1167-1179. http://dx. doi.org/10.1007/s00442-012-2384-y

Anteau, M. J., M. T. Wiltermuth, M. H. Sherfy, T. L. Shaffer, and A. T. Pearse. 2014. The role of landscape features and density dependence in growth and fledging rates of Piping Plovers in North Dakota, USA. The Condor 116(2):195-204. http://dx.doi. org/10.1650/CONDOR-13-001-R1.1

Baasch, D. M., T. J. Hefley, and S. D. Cahis. 2015. A comparison of breeding population estimators using nest and brood monitoring data. Ecology and Evolution 5(18):4197-4209. http:// dx.doi.org/10.1002/ece3.1680

Baasch D. M., P. D. Farrell, J. M Farnsworth, and C. S. Smith. 2017. Nest-site selection by Interior Least Terns and Piping Plovers at managed, off-channel sites along the Central Platte River in Nebraska, USA. Journal of Field Ornithology 88(3):236249. http://dx.doi.org/10.1111/jofo.12206

Bayard T. S., and C. S. Elphick. 2011. Planning for sea-level rise: quantifying patterns of saltmarsh sparrow (Ammodramus caudacutus) nest flooding under current sea-level conditions. Auk 128(2):393-403. http://dx.doi.org/10.1525/auk.2011.10178

Brooks, G. L., F. J. Sanders, P. D. Gerard, and P. G. R. Jodice. 2013. Daily survival rate for nests and chicks of Least Terns (Sternula antillarum) at natural nest sites in South Carolina. Waterbirds 36(1):1-10. http://dx.doi.org/10.1675/063.036.0101

Brown B. T., and R. R. Johnson. 1985. Glen Canyon Dam, fluctuating water levels, and riparian breeding birds: the need for management compromise on the Colorado River in Grand Canyon. Pages 76-80 in R. R. Johnson, C. D. Ziebell, D. R. Patten, P. F. Ffolliott, and R. H. Hamre, editors. Riparian ecosystems and their management: reconciling conflicting uses. USDA Forest Service, Fort Collins, Colorado, USA.

Brunton, D. H. 1997. Impacts of predators: center nests are less successful than edge nests in a large nesting colony of Least Terns. Condor 99(2):372-380. http://dx.doi.org/10.2307/1369943

Brunton, D. H. 1999. "Optimal” colony size for Least Terns: an inter-colony study of opposing selective pressures by predators. Condor 101(3):607-615. http://dx.doi.org/10.2307/1370190

Burger, J. 1987. Physical and social determinants of nest-site selection in Piping Plovers in New Jersey. The Condor 89(4):811818. http://dx.doi.org/10.2307/1368529

Burger J. 1988. Social attraction in nesting Least Terns: effects of numbers, spacing, and pair bonds. The Condor 90(3):575-582. http://dx.doi.org/10.2307/1368345

Burnham, K. P., and D. R. Anderson. 2002. Model selection and multimodel inference: a practical information-theoretic approach. Second edition. Springer, New York, New York, USA. http://dx. doi.org/10.1007/b97636

Catlin, D. H., J. D. Fraser, J. H. Felio, and J. B. Cohen. 2011. Piping Plover habitat selection and nest success on natural, managed, and engineered sandbars. Journal of Wildlife Management 75(2):305-310. http://dx.doi.org/10.1002/jwmg.46
Cohen J. B., L. M. Houghton, and J. D. Frazer. 2009. Nesting density and reproductive success of Piping Plovers in response to storm- and human-created habitat changes. Wildlife Monographs 173(1):1-24. http://dx.doi.org/10.2193/2007-553

Department of the Interior. 2006. Platte River Recovery Implementation Program final environmental impact statement. Bureau of Reclamation and Fish and Wildlife Service, Denver, Colorado, USA.

Dinan, J. J. 1982. Missouri River Interior Least Ternnesting survey. Report, Nebraska Game and Parks Commission, Lincoln, Nebraska, USA.

Dinsmore, S. J., G. C. White, and F. L. Knopf. 2002. Advanced techniques for modeling avian nest survival. Ecology 83(12):34763488. http://dx.doi.org/10.1890/0012-9658(2002)083[3476:ATFMAN] 2.0. $\mathrm{CO} ; 2$

Dugger, K.M., M.R. Ryan, and R.B. Renken. 2000. Least Tern chick survival on the Lower Mississippi River. Journal of Field Ornithology 71(2):330-338. http://dx.doi.org/10.1648/0273-8570-71.2.330

Dugger, K. M., M. R. Ryan, D. L. Galat, R. B. Renken, and J. B. Smith. 2002. Reproductive success of the Interior Least Tern (Sterna antillarum) in relation to hydrology on the Lower Mississippi River. River Research and Applications 18(2):97-105. http://dx.doi.org/10.1002/rra.634

Elias, S. P., J. D. Fraser, and P. A. Buckley. 2000. Piping Plover brood foraging ecology on New York barrier island ecology. Journal of Wildlife Management 64(2):346-354. http://dx.doi. org/10.2307/3803232

Elliott-Smith E., and S. M. Haig. 2004. Piping Plover (Charadrius melodus). In A. Poole, editor. The birds of North America. Cornell Lab of Ornithology, Ithaca, New York, USA. [online] URL: https://birdsna.org/Species-Account/bna/species/pipplo/introduction http:// dx.doi.org/10.2173/bna.2

Environmental Systems Research Institute (ESRI). 2011. Arc GIS Desktop: Release 10. ESRI, Redlands, California, USA.

Faanes, C. A. 1983. Aspects of the nesting ecology of Least Terns and Piping Plovers in central Nebraska. Prairie Naturalist 15:145154.

Fair, J., E. Paul, and J. Jones, editors. 2010. Guidelines to the use of wild birds in research. Ornithological Council, Washington, D. C., USA.

Goldin, M. R., and J. V. Regosin. 1998. Chick behavior, habitat use, and reproductive success of Piping Plovers at Goosewing Beach, RI. Journal of Field Ornithology 69:228-234.

Harris, W. C., D. C. Duncan, R. J, Franken, D. T. McKinnon, and H. A. Dundas. 2005. Reproductive success of Piping Plovers at Big Quill Lake, Saskatchewan. The Wilson Bulletin 117(2):165171. http://dx.doi.org/10.1676/04-046

Howell, T. R. 1959. A field study of temperature regulation in young Least Terns and common nighthawks. The Wilson Bulletin 71:19-32.

Jenks-Jay, N. 1982. Chick shelters decrease avian predation in Least Tern colonies on Nantucket Island, Massachusetts. Journal of Field Ornithology 53:58-60. 
Jenniges, J .J., and R. G. Plettner. 2008. Least Tern nesting at human created habitats in central Nebraska. Waterbirds 31 (2):274-282. http://dx.doi.org/10.1675/1524-4695(2008)31[274: LTNAHC]2.0.CO;2

Keldsen K. J., and D. M. Baasch. 2017. 2016 Interior Least Tern and Piping Plover monitoring and research report for the central Platte River, Nebraska. Platte River Recovery Implementation Program, Executive Director's Office, Kearney, Nebraska, USA. [online] URL: https://www.platteriverprogram.org/PubsAndData/ ProgramLibrary/PRRIP\%202016\%20Tern\%20and\%20Plover\% 20Monitoring $\% 20$ and $\% 20$ Research $\% 20$ Report.pdf

Kirsch, E. M. 1996. Habitat selection and productivity of Least Terns on the Lower Platte River, Nebraska. Ecological Monographs 132:1-48.

Krogh, M. G., and S. H. Schweitzer. 1999. Least Terns nesting on artificial habitats in Georgia, USA. Waterbirds 22(2):290-296. http://dx.doi.org/10.2307/1522218

Kruse, C. D., K. F. Higgins, and B. A. Vander Lee. 2001. Influence of predation on Piping Plover, Charadrius melodus, and Least Tern, Sterna antillarum, productivity along the Missouri River in South Dakota. Canadian Field Naturalist 115:480-486.

Laake J. L., D. S. Johnson, and P. B. Conn. 2013. Marked: an R package for maximum likelihood and markov chain Monte Carlo analysis of capture-recapture data. Methods in Ecology and Evolution 4(9):885-890.

Le Fer, D., J. D. Frazer, and C. D. Kruse. 2008. Piping Plover chick foraging, growth, and survival in the Great Plains. Journal of Wildlife Management 72(3):682-687. http://dx.doi. org/10.2193/2007-097

Loegering, J. P., and J. D. Fraser. 1995. Factors affecting Piping Plover chick survival in different brood-rearing habitats. Journal of Wildlife Management 59(4):646-655. http://dx.doi.org/10.2307/3801940

Maxson, S. J., and K. V. Haws. 2000. Population studies of Piping Plovers at Lake of the Woods, Minnesota: 19-year history of a declining population. Waterbirds 23(3):475-481.

McGowan, C.P., J. J. Millspaugh, M. R. Ryan, C. D. Cruse, and G. Pavelka. 2009. Estimating survival of precocial chicks during the prefledging period using a catch-curve analysis and countbased age-class data. Journal of Field Ornithology 80(1):79-87. http://dx.doi.org/10.1111/j.1557-9263.2009.00207.x

Melvin, S. M., L. H. MacIvor, and C. R. Griffin. 1992. Predator exclosures: a technique to reduce predation at Piping Plover nests. Wildlife Society Bulletin 20:143-148.

Murphy, R. K., M. J. Rabenberg, M. L. Sondreal, B. R. Casler, and D. A. Guenther. 2000. Reproductive success of Piping Plovers on Alkali Lakes in North Dakota and Montana. Prairie Naturalist 32:233-241.

Murphy, R. K., I. M. G. Michaud, D. R. C. Prescott, J. S. Ivan, B. J. Anderson, and M. L. French-Pombier. 2003. Predation on adult Piping Plovers at predator exclosure cages. Waterbirds 26 (2):150-155. http://dx.doi.org/10.1675/1524-4695(2003)026[0150: POAPPA]2.0.CO;2

Nguyen, L. P., K. F. Abraham, and E. Nol. 2006. Influence of arctic terns on survival of artificial and natural semipalmated plover nests. Waterbirds 29(1):100-104. http://dx.doi. org/10.1675/1524-4695(2006)29[100:IOATOS]2.0.CO;2

Patterson, M. E., J. D. Fraser, and J. W. Roggenbuck. 1991. Factors affecting Piping Plover productivity on Assateague Island. Journal of Wildlife Management 55(3):525-531. http://dx. doi.org/10.2307/3808985

Platte River Recovery Implementation Program (PRRIP). 2006. Final Platte River Recovery Implementation Program Adaptive Management Plan. U.S. Department of the Interior, State of Wyoming, State of Nebraska, State of Colorado.

Platte River Recovery Implementation Program (PRRIP). 2012. PRRIP Tern and Plover minimum habitat criteria. Executive Director's Office for the Governance Committee of the Platte River Recovery Implementation Program, Kearney, Nebraska, USA. [online] URL: https://www.platteriverprogram.org/ PubsAndData/ProgramLibrary/PRRIP\%202012_LTPP $\% 20$ Min $\%$ 20Habitat $\% 20$ Criteria_Draft.pdf

Platte River Recovery Implementation Program [PRRIP]. 2015a. Central Platte River Tern and Plover monitoring and research protocol. Executive Director's Office for the Governance Committee of the Platte River Recovery Implementation Program, Kearney, Nebraska, USA. [online] URL: https://www. platteriverprogram.org/PubsAndData/ProgramLibrary/PRRIP $\%$ 202017\%20Central\%20Platte\%20River\%20Tern \%20and \%20Plover $\%$ 20Monitoring $\% 20$ and $\% 20$ Research $\% 20$ Protocol.pdf

Platte River Recovery Implementation Program [PRRIP] 2015b. Final statement-PRRIP tern and plover habitat synthesis chapters. Executive Director's Office for the Governance Committee of the Platte River Recovery Implementation Program, Kearney, Nebraska, USA. [online] URL: https://www. platteriverprogram.org/PubsAndData/ProgramLibrary/PRRIP\% 202015_Tern $\% 20$ and $\% 20$ Plover $\% 20$ Habitat $\% 20$ Synthesis $\% 20$ Chapters. pdf

Powell, A. N. 2001. Habitat characteristics and nest success of snowy plovers associated with California Least Tern colonies. Condor 103(4):785-792. http://dx.doi.org/10.1650/0010-5422 (2001)103[0785:HCANSO]2.0.CO;2

R Development Core Team. 2015. R: A language and environment for statistical computing. R Foundation for Statistical Computing, Vienna, Austria. [online] URL: http://www.R-project.org/

Rotellam, J. J., M. L. Taper, and A. J. Hansen. 2000. Correcting nesting-success estimates for observer effects: maximumlikelihood estimates of daily survival rates with reduced bias. The Auk 117(1):92-109. http://dx.doi.org/10.1642/0004-8038(2000) 117[0092:CNSEFO]2.0.CO;2

Schweitzer, S. H., and D. M. Leslie, Jr. 1999. Nesting habitat of Least Terns (Sterna antillarum athalassos) on an inland alkaline flat. American Midland Naturalist 142(1):173-180. http://dx.doi. org/10.1674/0003-0031(1999)142[0173:NHOLTS]2.0.CO;2

Schweitzer, S. H., and D. M. Leslie, Jr. 2000. Stage-specific survival rates of the endangered Least Tern (Sterna antillarum) in northwestern Oklahoma. Proceedings of the Oklahoma Academy of Science 80:53-60.

Sherfy M. H., J. H. Stucker, and M. J. Anteau. 2009. Missouri River emergent sandbar habitat monitoring plan-a conceptual 
framework for adaptive management. Open file report 2008-1223, U.S. Geological Service and U.S. Army Corps of Engineers, Washington, D.C., USA. [online] URL: https://pubs.er.usgs.gov/ publication/ofr20081223

Sherfy M. H., J. H. Stucker, and D. A. Buhl. 2012. Selection of nest-site habitat by Interior Least Terns in relation to sandbar construction. Journal of Wildlife Management 76(2):363-371. http://dx.doi.org/10.1002/jwmg.301

Sidle, G. S., D. E. Carlson, E. M. Kirsch, and J. J. Dinan. 1992. Flooding: mortality and habitat renewal for Least Terns and Piping Plovers. Colonial Waterbirds 15(1):132-136. http://dx.doi. org/10.2307/1521363

Szell, C. C., and M. S. Woodrey. 2003. Reproductive Ecology of the Least Tern along the Lower Mississippi River. Waterbirds 26 (1):35-43. http://dx.doi.org/10.1675/1524-4695(2003)026[0035: REOTLT]2.0.CO;2

Thompson, B. C., J. A. Jackson, J. Burger, L. A. Hill, E. M. Kirsch, and J. L. Atwood. 1997. Least Tern (Sterna antillarum). In A. Poole and F. Gill, editors. The birds of North America online. Cornell Lab of Ornithology, Ithaca, New York, USA. [online] URL: https://birdsna.org/Species-Account/bna/home http://dx. doi.org/10.2173/bna. 290

U.S. Department of Agriculture: Natural Resources Conservation Service (NRCS); Farm Service Agency (FSA); Rural Development (RD). 2016. Geospatial Data Gateway. USDA Natural Resources Conservation Service, Washington, D.C., USA. [online] URL: http://dx.doi.org/10.15482/USDA.ADC/1241880

Whitehead P. J., and K. Tschirner. 1990. Magpie goose, Anseranas semipalmata, nesting on the Mary River Floodplain, Northern Territory, Australia: extent and frequency of flooding losses. Australian Wildlife Research 17(2):147-157. http://dx.doi. org/10.1071/WR9900147

Whitman, P. L. 1988. Biology and conservation of the endangered Interior Least Tern: a literature review. Biological Report 88(3). U.S. Department of the Interior, U.S. Fish and Wildlife Service, Division of Endangered Species, Washington, D.C., USA.

Whittier, J. B., and D. M. Leslie, Jr. 2009. Survival and movement of chicks of the Least Tern (Sterna antillarum) on an Alkaline Flat. The Southwestern Naturalist 54(2):176-181. http://dx.doi. org/10.1894/MH-29.1

Editor-in-Chief: Keith A.Hobson Subject Editor: Erica Nol
Sponsored by the Society of Canadian Ornithologists and Bird Studies Canada Parrainée par la Société des ornithologistes du Canada et Etudes d'oiseaux Canada

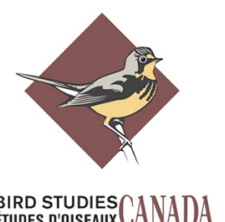

